20. Институт русской литературы Российской Академии наук (ИРЛИ РАН) (Пушкинский дом). Ф. 445 - Е.С. Зарудная-Кавос. Д. 43.

21. Институт русской литературы Российской Академии наук (ИРЛИ РАН) (Пушкинский дом). Ф. 445 - Е.С. Зарудная-Кавос. Д. 44.

22. Веременко В.А. Пансионы в России во второй половине XIX - начале XX в. // Вестник Ленинградского государственного университета им. А.С. Пушкина. 2015. № 3. С. 33-39.

23. А-ская. Из записок матери // Свободное воспитание. 1907/8. № 10.

24. Дурылин С. Общественное педагогическое творчество // Свободное воспитание. 1907/8. № 9. C. $100-103$.

25. ОР РНБ. Ф. 744 - В.Я. Стоюнин. Д. 302.

26. ОР РНБ. Ф. 163 - Второвы. Д. 370.

27. Веременко В.А. Детские сады и вопрос о социализации детей дошкольного возраста в дворянско-интеллигентских семьях России второй половины XIX - начала XX в. // История повседневности. 2017. № 3 (5). С. 99-111.

28. М.К. Опыт семейной школы в Москве // Свободное воспитание. 1907/8. № 1. С. 51-59.

29. Горбунов-Посадов И. Заметка о московском «Кружке совместного воспитания и образования детей» и «Детском саде М.А. Гуцевич» // Свободное воспитание. № 6. С. 109-111.
30. А.Т. Еще одна попытка свободного воспитания и образования // Свободное воспитание. 1908/1909. № 1. С. 5-32.

31. Соломин Е. Физическое воспитание и развитие самодеятельности учащихся в Тенишевском училище (в СПб.) // Свободное воспитание. 1909/10. № 4. C. 23-34.

32. Гаген-Торн Н.И. Memoria / сост., предисл., послесл. и примеч. Г.Ю. Гаген-Торн. М.: Возвращение, 1994. 415 с.

33. Беленцов С.И. Юношеское самоуправление: укрепление дисциплины или формирование сознательности (исторический аспект) // Вестник ПСТГУ. Серия 4: Педагогика. Психология. 2013. № 4 (31).

34. ОР РНБ. Ф. 744. Д. 347.

35. Центральный государственный исторический архив г. Санкт-Петербург (ЦГИА СПб.). Ф. 144. ОП. 1. Д. 77.

36. ЦГИА СПб. Ф. 144. ОП. 1. Д. 41.

37. ОР РНБ. Ф. 254 - Добиаш-Рождественская О.А. Д. 480.

38. Шик С.В. Развитие «внутреннего человека» у подростков начала XX века как педагогическая проблема // Сибирский педагогический журнал. 2009. № 3. С. 237-242.

39. Беленцов С.И. Духовно-нравственные основы гражданского воспитания юношества в России конца XIX - начала XX в. // Вестник ПСТГУ. Серия 4: Педагогика. Психология. 2013. № 28 (1).

\title{
UPBRINGING OF A REVOLUTIONARY: THE CONCEPT OF «FREE EDUCATION» IN ELITE SCHOOLS IN LATE XIX - EARLY XX CENTURIES RUSSIA
}

(C) 2018

Veremenko Valentina Alexandrovna, doctor of historical sciences, professor, head of Russian History Department Pushkin Leningrad State University (Pushkin, Saint Petersburg, Russian Federation)

Abstract. The paper explores the influence of pedagogical concept of «free education» on the formation of the world view of adolescents from the noble-intelligent families of Russia at the end of the XIX - beginning of the XX century. Attention is drawn to the fact that this pedagogical setup could be fully realized only in elite educational institutions. It is concluded that the «new ideological parents» and «advanced schools» carried out a single educational approach, focused on formation of a special intelligentsia opposition, accepting, or even supporting, all means in the struggle of «citizens» for «freedom». Despite the fact that the group of «new ideological parents» could not have been a mass phenomenon by the beginning of the XX century, it, at the same time, spread its influence both to the rest of educated population of the country and to the Ministry of Public Education, which, in favor of advanced pedagogy, agreed on the widespread introduction of individual ideas of free education in secondary schools. As a result of purposeful efforts of family and school, young people from the early youth were drawn into political activity, which became one of the essential factors of the revolutionization of the Russian society.

Keywords: Russia; early XX century; nobility; intelligentsia; family and school unity; free education; civic education; adolescents; elite educational institutions; teachers; new ideological parents; oppositionism; revolutionization.

УДК 94 (73)

Статья поступила в редакцию 19.11.2017

\section{ПЛАН ГОЭЛРО В ОЦЕНКЕ ПРЕССЫ США И ВЕЛИКОБРИТАНИИ 1920-1929 ГОДОВ} (C) 2018

Буранок Сергей Олегович, доктор исторических наук, профессор кафедры всеобщей истории, права и методики обучения Самарский государственный социально-педагогический университет (2. Самара, Российская Федераџия)

Аннотащия. В данной статье предпринято исследование того, какое место и значение занимал план электрификации России и его реализация в общественном мнении Великобритании и США. Изучение информационной кампании вокруг плана ГОЭЛРО в контексте методов и подходов исторической имагологии имеет свою специфику и значение: во-первых, это даёт возможность установить новые, неизвестные факты; вовторых, определить уровень информированности «другого» (в данном случае американского) общества о советской энергетике; в-третьих, понять, какое место информация о плане ГОЭЛРО занимала в США и Великобритании в системе построения образа СССР, образа «советской энергетической революции», для решения 
каких внутри- и внешнеполитических проблем образ советской энергосистемы актуализировался в американском обществе 1920-1929 гг.

В статье использованы материалы прессы США и Великобритании о плане ГОЭЛРО. Кроме того, на их основе проанализированы становление и восприятие образа советской энергетики в американском и британском обществе. Информационная кампания вокруг плана ГОЭЛРО смогла не только сообщить миру об успехах советской экономики, о правильности выбора приоритетов развития, но и способствовала подготовке (в информационном плане) следующего крупного проекта - индустриализации. А в глобальном плане статьи, репортажи, заметки о плане ГОЭЛРО помогли изменить отношение к России/СССР в США и Великобритании, помогли скорректировать образ СССР в мире.

Ключевые слова: электрификация; экономика СССР; план ГОЭЛРО; периодическая печать США; энергосистемы СССР; советская тяжёлая промышленность; историческая имагология; периодическая печать Великобритании; Г. Уэллс; В.И. Ленин; общественное мнение; Днепрогэс; экономическое развитие СССР; индустриализация.

Вопрос об отражении в американской и британской прессе экономических успехов СССР предвоенного периода достаточно популярен в историографии. Существуют исследования об оценке газетами США индустриализации [1, с. $115 ; 2$, с. 266; 3, с. 227], коллективизации [4, с. 14]. Они доказывают, что значительные изменения в социально-экономическом устройстве СССР всегда находились под пристальным вниманием американских и английских периодических изданий. Однако такое масштабное событие, как реализация плана ГОЭЛРО и, соответственно, реакция прессы США и Великобритании на него, ещё не стало предметом специального исторического исследования.

Изучение информационной кампании вокруг плана ГОЭЛРО в контексте методов и подходов исторической имагологии имеет свою специфику и значение: во-первых, это даёт возможность установить новые, неизвестные факты; во-вторых, определить уровень информированности «другого» (в данном случае американского) общества о советской энергетике; в-третьих, понять, какое место информация о плане ГОЭЛРО занимала в США и Великобритании в системе построения образа СССР, образа «советской энергетической революции», для решения каких внутри- и внешнеполитических проблем образ советской энергосистемы актуализировался в американском обществе 1920-1929 гг.

Первые сообщения в прессе США о будущих радикальных изменениях в энергосистеме Советской России появились ещё в начале 1920 г. 17 января 1920 г. в «Chicago Daily Tribune» была опубликована заметка об увеличении торговли с большевиками: журналист Генри Уэллс отметил, что, кроме еды, «красных лидеров» очень интересуют сырьё и промышленные технологии [5]. Продолжая эту тему в газете, Уильям Пол анализирует последствия захвата «красными армиями» Донбасса: доступ советского правительства к углю должен решить хотя бы некоторые проблемы.

А в статье от 30 января в «New York Times» pacсказывается, что часть из 400 компаний Нью-Йорка готова пойти на деловые контакты с большевиками, даже если официальные лица относятся к этому негативно. И как один из примеров такой фирмы названа «Western Electric Company» [6]. 2 февраля 1920 года «Chicago Daily Tribune» выходит с заголовком на первой полосе «Россия просит мир о торговле» [7].

В британской прессе первый масштабный интерес к будущему плану ГОЭЛРО проявился в конце февраля 1920 г. Два издания - «Dundee Evening Te- legraph» (Шотландия) и «Portsmouth Evening News» (Англия) - опубликовали цитаты В.И. Ленина и комментарии к ним. Для английских читателей 23 февраля 1920 года впервые было показано, что Россия планирует «электрификацию всей страны». План должен быть реализован в течение определённого количества лет. По словам Ленина, приводимых в статьях, «... электрификация омолодит Россию ... электрификация, основанная на советских принципах, принесёт полную победу основам коммунизма» [8; 9].

Все эти часто небольшие и разрозненные заметки и материалы в первой половине 1920 г. не могли изменить наиболее актуального образа России - «страна, в которой погибли мораль, закон и общество». Тем не менее публикации о налаживании торговой деятельности, первые контракты на поставку сырья и оборудования, первый интерес Советской России к технологиям не остались не замеченными прессой США и Великобритании. Но в январе-феврале 1920 г. далеко идущих выводов из этого не было сделано.

В декабре 1920 г. происходит сразу несколько информационных событий, способствующих актуализации и переосмыслению образа советской промышленности и энергосистемы, в частности. Прежде всего, необходимо отметить знаменитую серию статей Герберта Уэллса «Россия во мгле», которая печаталась на страницах британской газеты «Sunday Express» и американской «New York Times». 5 декабря 1920 г. «New York Times» выходит с пятым очерком писателя - «Мечтатель в Кремле» (в русском переводе утвердился вариант «Кремлёвский мечтатель») [10].

Важно отметить, что газетная публикация Уэллса была разделена на части, каждая со своим заголовком, а при переводе и издании очерков в виде книги эти заголовки исчезли. Один из них гласит: «Великий электрический план». Далее Уэллс раскрывает детали и своё отношение к данному плану: «Дело в том, что Ленин, который, как подлинный марксист, отвергает всех "утопистов", в конце концов сам впал в утопию, утопию электрификации. Он делает всё, что от него зависит, чтобы создать в России крупные электростанции, которые будут давать целым губерниям энергию для освещения, транспорта и промышленности. Он сказал, что в порядке опыта уже электрифицированы два района. Можно ли представить себе более дерзновенный проект в этой огромной равнинной, покрытой лесами стране, населённой неграмотными крестьянами, лишённой источников водной энергии, не имеющей технически грамотных людей, в которой почти угасли торговля и промышленность?» [11]. 
Этот же очерк находит широкое распространение на страницах британских газет [12; 13]. Эдинбургское издание «The Scotsman» отнеслось к материалам Уэллса весьма скептически, указав, что мистер Уэллс хотя и пришёл в восторг от грандиозных планов электрификации, но как это сделать малограмотным крестьянам - не ясно [14].

Из текста статьи Уэллса видно, что американская и британская общественность получили в конце 1920 г. ответ на вопрос, волновавший их в начале года: для чего нужны большевикам технологии и сырьё. И наиболее важными здесь являются слова, что реализация плана уже идёт. Однако эта важная информация «утонула» в мрачных образах России, актуализированных Уэллсом буквально в следующем предложении.

Более того, недоверие к ленинскому плану, выраженное Уэллсом в статье, хорошо вписывалось в общий контекст советско-американских (а если смотреть шире - русско-американских) отношений начала XX в. Подобный образ был традиционным не только для 1920 г.: ещё начиная со второй половины XIX в. образ России строился на противопоставлении «цивилизации» - «варварства», где обществонаблюдатель (США) выступало с позиций цивилизации, актуализируя тем самым в собственных глаза свою историческую миссию в просвещении других стран. Поэтому, несмотря на очень важную информацию о планах Ленина, в том числе и о плане ГОЭЛРО, статья Уэллса не произвела в США и Великобритании сенсации. Она была перепечатана в «Boston Daily Globe», «Chicago Daily Tribune», «Times». Но переломить ситуацию с образом России она не смогла в силу традиционного базиса, на котором строился Уэллсом образ Советской России. Однако очерки Уэллса достигли успехов в другом смогли дать старт созданию нового образ советской энергетики (или шире - промышленности).

Практически сразу после публикации пятого очерка Уэллса появляется целая серия статей в «New York Times» с сенсационными заголовками: «Ленин потратит 3 млрд долларов», «Россия собирается заказать у американских бизнесменов товаров на 3 млрд долларов» $[15 ; 16]$. Данный материал появился после возвращения известного предпринимателя Вашингтона Вандерлипа из России. В статье Вандрелип рассказывал не только о своих планах на концессии в Сибири и Камчатке, но и о том, на что Ленин собирается потратить такую фантастическую сумму: прежде всего на проведение в жизнь плана, упомянутого Уэллсом, - плана электрификации страны.

Параллельно с этим ведущая газета США напечатала материал о контактах советского правительства со Швейцарией, где его особенно «интересовало электрооборудование, электромоторы и швейцарские инженеры и специалисты по электричеству» [17]. Другие периодические издания США тоже развивают эту тему: взаимосвязь амбиционных планов Ленина по электрификации России и невероятных планируемых объёмов торговли с США [18; 19].

Итогом этой небольшой, но яркой информационной кампании становится публикация в «New York Times» 24 декабря 1920 г. статьи «Ленин раскрывает планы. Возрождение экономики России зависит от электрификации» [20]. Это первая статья после пуб- ликации Г. Уэллса, где достаточно подробно рассказывается о деталях плана ГОЭЛРО.

Начинается статья с информации (со ссылкой на Лондон), что «Николай Ленин (в прессе США периода 1917-1922 г2. использовался такой псевдоним В.И. Ленина. - прим. авт.) - советский премьер, представил на Всероссийском съезде Советов план по восстановлению экономики страны» [20]. Именно в таком варианте американская общественность узнала о постановлении Совета Народных Комиссаров от 21 декабря «О плане электрификации России». Между этой публикацией и статьёй $Г$. Уэллса лежат существенные различия.

Во-первых, в статье знаменитого писателя план электрификации выглядел нереальным из-за постоянного подчёркивания автором статьи таких выражений, как «кремлёвский мечтатель», «утопия Ленина», «сверхфантазии», «волшебство». В статье от 24 декабря речь идёт об уже принятом постановлении советского правительства, т.е. реальной программе, которая начинает выполняться.

Во-вторых, статья Г. Уэллса касалась очень многих вопросов - прежде всего, формирования образа Ленина для американских и британских граждан. И тема электрификации была для писателя вспомогательной, чтобы показать широту и дерзость взглядов советского лидера. В анонимной статье от 24 декабря речь идёт только об электрификации и всё внимание читателей концентрируется на этой проблеме.

В-третьих, наверное, самое важное обстоятельство - публикация Г. Уэллса была первой, единственной, где поднялся вопрос о плане ГОЭЛРО. Эта тема практически не фигурировала в прессе США, за исключением отдельных, разрозненных упоминаний. Материал от 24 декабря оказался подкреплённым достаточно солидной информационной базой в виде статей начала декабря 1920 г., в которых рассказывалось об интересе России к технологиям, электричеству, специалистам, а самое главное, информация была поддержана цифрами финансовых расходов большевиков на план ГОЭЛРО, которые публиковались с подачи Вашингтона Вандерлипа.

Таким образом, эти выделенные три обстоятельства обеспечили совершенно иное отношение прессы к словам В.И. Ленина о масштабной электрификации России. «Утопия Уэллса и Ленина» превратилась в программу, поставив прессу США перед выбором: как к ней относиться - поддерживать или критиковать.

В следующий, 1921 год, проблема электрификации станет достаточно значимой частью глобального «русского вопроса» на страницах прессы США и Великобритании. Важно отметить, что газеты Великобритании первыми возобновили интерес к советскому плану. Уже 10 января 1921 г. издание «Globe» (Лондон) напечатало информацию, что недавно принятый СНК план электрификации России, скорее всего, будет осуществлён с помощью концернов «Сименс» и «Крупп», т.к. союзники на подобную помощь большевикам никогда не согласятся. Газета особо указывала: «Общий размах плана - огромен и охватывает массу деталей, необходимых для постройки 27 новых электростанций» [21]. Такой же материал был опубликован и в «Dundee Evening Telegraph» [22]. 
Это была первая опубликованная в прессе конкретная информация об особенностях плана ГОЭЛРО, об отношении к нему представителей США и Великобритании и, кроме того, первые осторожные прогнозы о будущих партнёрах по его реализации. Общий тон публикации - крайне недоверчивый. А частые упоминания в «Globe» фирм Германии создавали у читателей представление о новом русскогерманском заговоре, как в случае с БрестЛитовским миром, воспоминания о котором были ещё весьма сильны в общественном мнении Великобритании. Из этих установок, публикуемых прессой, формировалось и общее отношение британской общественности к плану ГОЭЛРО - настороженное недоверие.

Это подтверждает следующая публикация в «Globe» от 12 января 1921 г.: «Следует надеяться, что союзники будут следить за германо-большевистским планом электрификации в России. Слишком много шокирующих инцидентов произошло в России» [23]. И хотя британские журналисты не указали, какие именно были «шокирующие инциденты», - всё это способствовало развитию крайне враждебного отношения к плану ГОЭЛРО как потенциальной «угрозы для союзников». 14 января 1921 г. газета «Dundee Evening Telegraph» подтвердила наличие «особого плана», который реализует в России «германо-большевистская компания», прикрываясь электрификацией [24].

Но идея заговора просуществовала достаточно недолго: уже в конце января 1921 г. пресса Великобритании переходит от поиска сенсаций к прогнозам развития плана ГОЭЛРО. «Sheffield Independent» (Южный Йоркшир) от 20 января сообщает, что Ленин планирует за несколько лет обеспечить всю страну электрическими лампами, дать электроэнергию заводам, а также электрифицировать городской транспорт. Однако глобальная цель - «электрификация всей России» - не осуществима. Газета ссылается на другие источники: «Новостные ленты заявляют, что этот план будет разрушен из-за нехватки железа и стали в России» [25].

Видно, что в начале 1921 г. газеты Великобритании уделили достаточно много вниманию новостям о планах электрификации России и отреагировали на это двумя способами: 1) формированием мифа о русско-германском заговоре; 2) негативными прогнозами о провале ленинского плана.

СМИ США в это же время при освещении плана ГОЭЛРО пошли несколько иным путём. Статьи и заметки, посвящённые этой теме в американской прессе, можно разделить условно на две группы.

Первая группа - это газетные публикации о торговле с Советской Россией. B «New York Times» и «Chicago Daily Tribune» 26 марта 1921 г. появляются сразу две статьи, где упоминается план ГОЭЛРО. Первый материал - «Надежды на увеличение русского экспорта снижаются» - повествует в скептическом тоне о бесперспективности планов Ленина по расширению торговли с Западом. Журналисты Ассошиэйтед пресс, подготовившие статью, ссылаются на финских, британских и американских бизнесменов и политиков, стремясь доказать невозможность в новой России индустриального рывка. Их рассуждения касаются и плана ГОЭЛРО: «Больше всего места в советских заказах занимает электрооборудование. Ленин, с его широкомасштабным планом электрификации России - самый большой энтузиаст, когдалибо существовавший. Но надежды на доверие к его огромному плану, способному спасти всю политикоэкономическую программу России, здесь [имеется в виду Европа] - быстро улетучиваются» [26].

Статья в «Chicago Daily Tribune» от того же дня прямо противоположной направленности. Материал описывает встречу полпреда и торгпреда в Великобритании Л.Б. Красина с британскими и американскими журналистами. Значительная часть цитат Красина, подобранных редакторами «Chicago Daily Tribune», касается торговли, экономики и промышленного развития новой России. В частности, Красин выражает надежды на увеличение торговли России и США, что «великий, свободолюбивый американский народ не будет долго терпеть напряжённые отношения и признает правильность русского выбора», что гарантирует все выплаты по долгосрочным кредитам [27].

Очевидно, что на журналистов слова Л.Б. Красина подействовали, и критический тон беседы сменился на конкретные вопросы о торговых интересах России. Советский представитель перечислил многие виды товаров и отдельно указал «электромашины и оборудование электростанций» [27]. Данная заметка была перепечатана многими влиятельными газетами в США [28; 29].

Эти два материала хорошо показывают общий настрой американской прессы, который в этот же день «Washington Post», описывая ту же беседу Л.Б. Красина, определила так: «Американская пресса почти единодушно одобряет заявление секретаря Хьюза, отказывающегося вступать в торговые отношения с Советами. Несмотря на острый бизнес-инстинкт, который требует коммерческой экспансии, американский дух не контролируется долларом» [30].

Борьбу этих двух течений можно наблюдать на страницах прессы США: выгода толкает бизнесменов к принятию плана Ленина и активизации торговли, в соответствии с заказами по плану ГОЭЛРО, а политическая ситуация заставляет эту торговлю искусственно сдерживать, тем самым подрывая одну из основ для реализации плана электрификации России.

Всю весну, лето и раннюю осень 1921 г. пресса США обсуждала эту проблему: нужно ли поддержать ленинский план своими товарами, деньгами и специалистами или, в соответствии с политикой госдепартамента, игнорировать любые советские заказы. Причем сторонники обоих вариантов находили разные способы повлиять на информационную ситуацию вокруг советской промышленности и электрификации, в частности. Так, в мае 1921 г. было опубликовано развёрнутое мнение известного политика, республиканца, сенатора Уильяма Бора, который доказывал большие перспективы торговли с Россией. По его мнению, для американской промышленности выгодно создать ещё один рынок сбыта в виде России, а развитие советской промышленности поможет американским компаниям в получении прибыли [31].

Вторая группа публикаций - это материалы, непосредственно затрагивающие вопросы промышленного развития и реализации плана ГОЭЛРО. Здесь тоже наблюдается борьба двух тенденций: «русофильской» и «русофобской». Для демонстра- 
ции утопичности плана Ленина по электрификации журналисты США прибегали в 1921 г. к простому, но эффективному методу: публикации мнений американских инженеров, побывавших в России. В «New York Times» 3 сентября 1921 г. размещена большая статья об инженере Рояле Кили, который «в течение многих месяцев был пленником в России». Наблюдения Р. Кили звучат как приговор ленинскому плану: «Промышленные заводы в России гниют, идёт постоянное разрушение прошлой индустриальной мощи». Отдельно указано, что Кили «несколько раз информировал советского премьера Николая Ленина об ужасном состоянии промышленности» [32; 33].

Подобные публикации полностью отражали настроения в лагере «русофобов», считающих, что после всех потрясений возрождение экономического потенциала Советской России - невозможно. А следовательно, по мнению данной когорты журналистов, все планы электрификации и обновления индустриальных объектов через заказы в США - не более чем советская пропаганда.

«Русофилы» или, по крайней мере, не так критично настроенные журналисты на это отвечали более оптимистическими статьями. Известный журналист Уолтер Дюранти 6 октября 1921 г. опубликовал в «New York Times» статью «Россия возвращается в индустриальную эру», где указывал на многие факторы роста советской промышленности, в том числе и на начало процесса электрификации [34]. Кроме этого, «Atlanta Constitution» сообщала, что завод американской компании «Вестингауз Электрик» на Волге не был национализирован и продолжает работу, опровергая тем самым сообщения об ужасах советской промышленности [35; 36].

Как видно, 1921 г. прошёл для американской прессы больше в скептических тонах, а большинство журналистов, за редким исключением, высказывало открытое недоверие к возможности реализации плана электрификации России. В 1922 г. новости о развитии энергетики в России почти не попадали в прессу США. Заметное исключение - статья в «New York Times» от 22 апреля. Материал, подготовленный агентством Ассошиэйтед пресс, вышел под заголовком «Штейнмец предложил России помощь в проектах электрификации» [37].

В статье рассказывается, что известный инженер, изобретатель, ведущий сотрудник компании «Дженерал Электрик» доктор Чарльз Штейнмец обратился к Ленину с предложением технической помощи или консультаций для реализации плана электрификации России. В статье указывается, что Ленин с благодарностью принял помощь от «одного из величайших учёных современности» [37]. Дело не ограничится лишь перепиской, и Ч. Штейнмец приедет в 1922 г. в Россию. В архиве учёного хранится его фотография вместе с В.И. Лениным и подписью: «Штейнмецу с благодарностью за то, что он - один из немногих учёных, который не противостоит пролетариату» [38].

С этой статьи начинается изменение отношения прессы к плану ГОЭЛРО, т.к. изменяется сам образ России/СССР. Теперь США на страницах периодических изданий выступают не просто в роли наблюдателя за хаосом и разрухой в далёкой стране, а в роли наставника и учителя, который несёт цивилизаци- онную миссию. Этот новый образ построен на прежних базисных принципах, главный из которых - противопоставление «цивилизации» и «варварства». И снова, как и в публикациях 1920-1921 гг., США выступают с позиций цивилизации.

Но даже столь небольшие изменения способствовали трансформации всей позиции прессы США, которая от прежнего скептицизма к плану электрификации России постепенно переходит к более взвешенной оценке, т.к. теперь журналисты в расчёт принимают американскую помощь Ленину, что, по их мнению, может стать решающим условием для выполнения амбициозной задачи.

В период 1923-1924 гг. появлялись лишь незначительные заметки, связанные с выполнением программы электрификации СССР. Пресса США и Великобритании практически забыла об этой теме, сосредоточившись на внутренних проблемах. Лишь осенью 1924 г. в газетах Америки и Англии проходит сенсационная информация, что «Советы строят 30 новых электростанций. Российское Советское правительство взяло на себя обязательство осуществить амбициозную программу развития гидроэнергетики, которая предусматривает строительство не менее тридцати электростанций, из которых семь находятся в стадии строительства, а пять находятся в процессе частичной эксплуатации» [39]. Эти сведения были получены от американского инженера Гарольда Базелла, профессора Университета Канзаса, поэтому не вызвали у журналистов никаких сомнений: реализация плана ГОЭЛРО идёт чрезвычайно быстрыми темпами, несмотря на весь недавний скептицизм Запада.

Пресса Британии также в сентябре 1924 г. вернулась к плану ГОЭЛРО. «Yorkshire Post and Leeds Intelligencer» писала в номере от 10 сентября о строительстве «новой электростанции «Красный Октябрь», способной дать электроэнергию всему Ленинграду. Если раньше электрификация была лишь словом, то теперь в России вновь пробудился дух инициативы» [40].

Успехи 1924 г. в выполнении плана ГОЭЛРО незамедлительно изменили настроение редакторов и журналистов США и Великобритании, хотя борьба между «скептиками» и «оптимистами» в СМИ была далека от завершения.

Новый всплеск интереса происходит в 1925 г. в связи со сдачей в эксплуатацию Шатурской ГРЭС. Первая статья в «New York Times» появилась ещё в июле 1925 г. В ней сообщалось, что в СССР введена в строй тепловая электростанция стоимостью в 80 млн долларов (или, как указывали журналисты, 160 млн золотых рублей). Наибольшее внимание газета уделила именно Шатурской ГРЭС, сообщая, с некоторым удивлением, что такой современный промышленный объект был построен главным образом советскими инженерами [41]. Ещё большую сенсацию вызвала информация о том, что в СССР уже функционируют построенные по ленинскому плану электрификации ГРЭС «Красный Октябрь» в Ленинградской области и Каширская ГРЭС в Московской области. Заканчивается строительство Штеровской ГРЭС и Волховской ГЭС.

Такие сообщения резко контрастировали с большинством других материалов прессы США и Вели- 
кобритании про СССР, построенных на актуализации маркера отсталости. В свете новой информации получалось, что «утопия электрификации» за 5 лет сделала значительный шаг вперёд. Однако в период 1924-1925 гг. публикаций об успехах плана ГОЭЛРО было относительно мало, хотя они и были напечатаны в одной из наиболее влиятельных и авторитетных газет США - «New York Times». Статьи с упоминаниями построенных и строящихся ГЭС и ГРЭС выполнили ещё одну важную функцию: подготовили американских журналистов (и читателей) к правильному восприятию и оценке следующих событий 1926 года.

В начале осени 1926 г. в СМИ США и Великобритании появилась первая информация о принятии в СССР решения по строительству крупной гидроэлектростанции на Днепре. «Washington Post» первой из американских газет сообщила об этом 17 сентября 1926 г.: «Американцам предлагается огромная советская концессия. Первые траты 5 млн долларов из 60 млн» [42]. В такой интригующей манере преподносились и остальные факты: «Концессия в размере 60.000 .000 долларов США для развития гидроэлектроэнергии на реке Днепр была предложена сегодня американской промышленной группе. Хью Купер из Нью-Йорка сообщил Алексею Ивановичу Рыкову, с которым у него была трёхчасовая конференция, что планы, предусматривающие расходование 60.000.000 долларов, будут приемлемы для американской стороны, если советское правительство сделает первоначальные ассигнования в размере 5.000.000 долларов США на покупку американской техники и оборудования» [42]. О том, что Х. Купер стал главным консультантом по проекту, газета не сообщает [43].

Как видно, первый материал о будущем Днепрогэсе выполнен в традиционном для американской прессы ключе: основной акцент сделан на участии США, на полученной и ожидаемой прибыли, а не на амбициозности и значимости советского плана. С такой же трактовкой события вышли номера «New York Times» [44] и «Los Angeles Times»: «Величайшая гидроэлектростанция будет разработана американцами для России» [45].

Однако другие ведущие периодические издания США отнеслись к этой новости более глубоко. «Boston Daily Globe» 7 октября 1926 г. выходит со статьей «Упряжь для Днепра», где характеризуется решение СССР начать строительство «гигантской гидроэлектростанции на Днепре» [46]. «Christian Science Monitor» также не стесняется на эпитеты по поводу новой советской ГЭС: «Великая гидроэлектростанция на Днепре», но в первых же предложениях редакторской статьи указано, что помощь СССР в разработке уникального проекта оказывает «всемирно известный инженер Хью Купер» [47]. В октябре 1926 г. и «Hartford Courant» информирует читателей о том, что «крупнейшая гидроэлектростанция будет построена на Украине» [48].

Пресса Великобритании осенью 1926 г. также обратила внимание на амбициозный проект на Днепре. Издание «The Scotsman» сообщало читателям, что в «СССР будет построена крупная электростанция на порогах на реке Днепр, недалеко от Кичкаса, стоимостью не более миллиона долларов» [49]. Здесь очевидна ошибка журналистов, сильно занизивших стоимость работ по созданию ГЭС. В других газетах Великобритании за осень 1926 года таких ошибок уже нет, зато содержится новая информация: «В СССР будет самый дешёвый электрический ток в мире. Американский инженер это заявил после ознакомления с проектом создания огромной ГЭС на Днепре. Этот проект привлекает всеобщее внимание» [50].

Можно констатировать, что в сентябре - октябре 1926 г. в прессе США и Великобритании проблема электрификации СССР стала весьма актуальной, т.к. о ней написали наиболее важные газеты как Западного, так и Восточного побережья США, а также Англии, Уэллса и Шотландии. До этого времени одновременно ещё никогда столько материала о реализации плана ГОЭЛРО в СМИ США и Великобритании не попадало.

Для такого информационного всплеска было несколько причин. Во-первых, привлечение значительных средств в американскую экономику, что откровенно льстило как редакторам газет, так и их читателям [51].

Во-вторых, участие в проекте знаменитого американского инженера Х. Купера полностью укладывалось в существующую у американского общества в середине 1920-х гг. картину мира: США находятся на вершине экономического могущества промышленного развития, следовательно, наиболее важная задача - обучение других народов законам американского успеха, т.е. выполнение цивилизационной миссии.

Благодаря сочетанию таких факторов долгий спор «русофобов» и «русофилов» в США вокруг ситуации с планом ГОЭЛРО, а также торговлей, промышленным развитием СССР, трансформировался в новую пропагандистскую модель: советская энергетика будет успешно развиваться, если будет продолжено сотрудничество с американскими компаниями и инженерами. Таким образом, первые очевидные успехи плана ГОЭЛРО были использованы журналистами США для детализации, прежде всего, Я-концепции американского общества.

К концу 1926 - началу 1927 гг. вопрос о Днепрогэсе становится центральным в проблеме «советской индустриализации». Он появляется практически во всех американских газетных материалах, связанных с развитием энергетики и промышленности СССР. Например, 7 декабря 1926 г. в «Christian Science Monitor» выходит статья «Россия получит дешёвую энергию», в которой указывалось, что реализация проекта «Днепр» обеспечит южные районы Советского Союза энергоресурсами и решит многие транспортные проблемы [52].

«Los Angeles Times» весной 1927 г. раскрывает некоторые детали «русского энергетического плана», касающиеся строительства 30 новых ГЭС и ГРЭС. Центральной стройкой объявлен Днепрогэс [53]. «Boston Daily Globe» в 1927 г. писала о применяемых при строительстве ГЭС на Днепре новых технологиях [54]. А летом 1928 г. Бостонское издание констатировало: советская дамба на Днепре - самая большая в мире, а затраты на её строительство уже составили 85 млн долларов [55]. В этом проявились несколько разные подходы американской и британской прессы к публикации информации о Днепрогэсе. Ес- 
ли американские журналисты всячески подчёркивали гордость за своих инженеров, за миллионы долларов, полученные от СССР, за размеры станции, то их британские коллеги расставляли акценты несколько иначе: «Огромный просчёт в смете. Советские власти обеспокоены растущей стоимостью Великой Днепровской ГЭС, пересмотренные данные показывают, что американские инженеры недооценили общий объём финансовых вложений» [56].

Но это не привело к появлению статей, предрекающих провал стройке на Днепре. Наблюдается всё большее смещение приоритетов: электрификация СССР становится важной частью информационного пространства США о России, тогда как в Великобритании отходит на второстепенные роли.

Указанные публикации в США создавали уже не только упомянутый ранее эффект: актуализации чувства гордости американцев за своих промышленных гениев, но и совершенно новый образ СССР, где могут быть не только самые большие пространства и равнины, но и уникальные промышленные, энергетические объекты, которым, как констатировали журналисты США, нет равных в мире.

Другие периодические издания с периодичностью раз в месяц (иногда раз в два месяца) поднимали вопрос об энергетике СССР, что со временем потребовало не только информационных зарисовок, но и аналитических материалов в СМИ США.

Одну из первых статей с анализом ситуации в промышленности в целом и в реализации плана ГОЭЛРО написал в 1928 г. Лев Кинчук для «Chicago Daily Tribune»: «Чиновники рисуют розовую картину советского прогресса» [57]. В публикации отмечено, что 1926-1927 гг. для советской «большой промышленности» были успешными - удалось увеличить производство на 19,8\%. Журналист отмечает: «Особенно значительные успехи в производстве электроэнергии: в 1913 г. Россия производила 1,945 млрд квтч, а в 1927-1928 гг. выросло до 5,145 млрд квтч и по прогнозам достигнет 6 млрд квтч в 1928-1929 гг.» [57]. Хотя эти цифры не совсем совпадают с советскими статистическими данными, они хорошо демонстрировали для американской публики главный эффект плана ГОЭЛРО - увеличение уже к 1928 г. почти в три раза показателей производства электроэнергии. Для страны, ещё 5 лет назад охарактеризованной американцами в СМИ как «государство без торговли, промышленности и морали», такие показатели воспринимались практически как индустриальное чудо. Завершает раздел об электроэнергии в статье Кинчука упоминание о «продолжении строительства великой гидроэлектростанции на Днепре». Даже традиционно скептически настроенная «Chicago Daily Tribune» признала: промышленный рост в СССР идёт большими скачками.

Следовательно, американским СМИ потребовалось 7-8 лет, чтобы от удивления и отрицания возможности электрификации России перейти к обсуждению конкретных этапов реализации и вероятных сроков завершения плана.

1929 год можно выделить как особый период в развитии американских оценок плана ГОЭЛРО. Публикации американской прессы о советской энергетике этого года делятся на две группы. Первая - статьи до «чёрного вторника» 29 октября 1929 г. Вторая - заметки и небольшие материалы после биржевого краха.

Первая группа статей выполнена в традиционном стиле предыдущего периода: это либо аналитические оценки темпов роста советской энергосистемы, либо сводки о потраченных СССР финансах на строительства ГРЭС и ГЭС, либо зарисовки «с места событий», интервью с американскими инженерами и бизнесменами. Своеобразной квинтэссенцией таких материалов является статья в «Chicago Daily Tribune» от 14 апреля 1929 года «Россия потратит 80 млн долларов, чтобы запрячь Днепр» [58]. Необходимо отметить, что для описания Днепростроя американцы часто использовали данный термин и его производные: «упряжь для Днепра», «укротить Днепр», прибегая тем самым к достаточно простому метафоричному ряду, показывающему читателям всю сложность и масштаб работы.

Данную статью в чикагской газете написал известный латвийский писатель и журналист Марк Разумный. Начинается материал с описания небольшого городка Запорожье, рядом с которым «советское правительство строит огромную дамбу, которая даст энергию большей части Украины, улучшит ирригационные системы и откроет Днепр как судоходный путь из Чёрного моря в Центральную Россию» [58]. Такое начало статьи достаточно сильно отличается от предыдущих материалов американских газет, которые концентрировали внимание прежде всего на размерах потраченных сумм и масштабах будущих промышленных объектов.

Всё это присутствует и в статье от 14 апреля 1929 г., но лишь на втором плане либо как приманка для читателей в заголовке. Основу же первого материала составляют глобальные задачи, решаемые правительством СССР с помощью ГЭС на Днепре. Такого количества задач (три) не было озвучено ещё ни в одной американской статье. Поэтому план ГОЭЛРО предстаёт здесь перед американской публикой, действительно, в виде средства, способного спасти всю экономику Советского Союза.

Но это не единственная отличительная черта статьи М. Разумного: он объясняет для американских читателей новое слово «Dnieprostroy» - «советское название проекта, трудоустроившего 10.000 рабочих и инженеров» [59]. И далее автор называет «Dnieprostroy» русским Клондайком, т.к. проект привлёк тысячи людей со всей России. Видно, что журналист не просто демонстрирует важность ГЭС на Днепре для экономики СССР, но делает это в новых, запоминающихся и понятных для американских граждан выражениях.

Новый термин окажется очень популярным у американских и британских журналистов и прочно войдёт в таком же виде в историографию, в том числе и современную [60; 61].

К 1929 г. сомнения в возможности СССР выполнить амбициозный план электрификации полностью исчезли со страниц американских и британских изданий. Они уступили место новым публикациям об использовании построенных за 1920-1929 гг. ГРЭС и ГЭС, для нового масштабного советского проекта индустриализации. С 1929 года наблюдается резкое изменение подходов прессы США и Великобритании к освещению промышленного развития СССР, осо- 
бенно на фоне мирового экономического кризиса. В новых информационных условиях ленинский план электрификации стал получать, особенно от американских журналистов, самые уважительные оценки и характеристики.

Можно выделить следующие этапы в процессе формирования американской и британской прессой оценок плана электрификации России/СССР

Первый этап: январь - декабрь 1920 г. Характеризуется небольшим количеством коротких заметок о торговой активности России, особенно на рынке энергетических технологий. Общий фон освещения ситуации в России: произошла масштабная социально-экономическая и политическая катастрофа, от которой Россия уже не оправится. Статья Г. Уэллса этот настрой прессы Запада сильно не изменила.

Второй этап: декабрь 1920-1922 гг. Характеризуется обсуждением общих моментов плана ГОЭЛРО. Отношение прессы Великобритании, особенно в начале 1921 г., - недоверчивое и настороженное; пресса США связывает план электрификации с дискуссий о торговле с Россией. Происходит размежевание журналистов по этой позиции на «русофилов» и «русофобов».

Третий этап: 1922-1924 гг. Наблюдается определённое «затишье» в период 1922-1923 гг. Но с осени 1924 г. начинается радикальное изменение отношения прессы США и Великобритании к плану электрификации: сообщения о строительстве сразу 30 новых ГРЭС и ГЭС, факты привлечения крупных денежных средств и иностранной помощи заставляют западных журналистов писать о реальном выполнении ленинского плана и обсуждать не русскую отсталость, а перспективы и выгоды экономики СССР от реализации плана ГОЭЛРО.

Четвертый этап: 1925-1926 гг. Характеризуется публикацией серии сенсационных статей о значительных успехах советской промышленности и энергетики. Пресса США и Великобритании внимательно следит за строительством и вводом в эксплуатацию Шатурской, Каширской, Штеровской ГРЭС. Такие статьи создают новый образ советской промышленности - современной и способной решать самые сложные задачи. Этот период можно выделить как время победы над «скептиками» среди журналистов США и Великобритании.

Пятый этап: 1926-1929 гг. Его можно обозначить как этап Днепрогэса, или «Днепростроя». Практически все публикации английской и американской прессы о советской энергетике касаются Днепрогэса. Журналисты снабжают будущую ГЭС эпитетами «великая», «огромная», «гигантская». Актуализируется образ современного, индустриального, готового к сотрудничеству с Западом СССР. Маркер отсталости и варварства, столь популярный в начале 1920-х гг. для изображения ситуации в России, в 1929 г. используется значительно меньше, а в публикациях о Днепрогэсе - никогда.

Информационная кампания вокруг плана ГОЭЛРО смогла не только сообщить миру об успехах советской экономики, о правильности выбора приоритетов развития, но и способствовала подготовке (в информационном плане) следующего крупного проекта - индустриализации. А в глобальном плане статьи, репортажи, заметки о плане ГОЭЛРО помогли изме- нить отношение к России/СССР в США и Великобритании, помогли скорректировать образ СССР в мире.

\section{Список литературы:}

1. Резаненко О.О. Американская пресса о советской индустриализации в 1920-1930-е годы // Самарский научный вестник. 2015. № 2. С. 115-119.

2. Шпотов Б.М. Американская и российская печать о советской индустриализации // Американская проблематика в периодике XVIII-XX вв. М., 2004. C. 266-276.

3. Шпотов Б.М. Американские участники индустриализации СССР: некоторые оценки и впечатления 1930-х годов // Американский ежегодник. 2012. № 2012. С. 227-245.

4. Левин Я.А. Образ «кулака» в американской прессе 1924-1930-х гг. // Электронный научно-образовательный журнал История. 2014. № 7 (30). С. 14.

5. Chicago Daily Tribune. 1920. January 17.

6. New York Times. 1920. January 30.

7. Chicago Daily Tribune. 1920. February 2.

8. Dundee Evening Telegraph. 1920. February 23.

9. Portsmouth Evening News. 1920. February 23.

10. New York Times. 1920. December 5.

11. Уэллс Г. Россия во мгле: пер. с англ. / с предисл. Н.С. Трубецкого. София: Российско-болгарское кн-во, 1921. XVI. 96 с.

12. Aberdeen Press and Journal. 1920. November 30.

13. Falkirk Herald. 1920. December 8.

14. The Scotsman. 1920. December 13.

15. New York Times. 1920. December 12.

16. New York Times. 1920. December 13.

17. New York Times. 1920. December 7.

18. Atlanta Constitution. 1920. December 20.

19. Atlanta Constitution. 1920. December 25.

20. New York Times. 1920. December 24.

21. Globe. 1921. January 10.

22. Dundee Evening Telegraph. 1921. January 12.

23. Globe. 1921. January 12.

24. Dundee Evening Telegraph. 1921. January 14.

25. Sheffield Independent. 1921. January 20.

26. New York Times. 1921. March 26.

27. Chicago Daily Tribune. 1921. March 26.

28. Christian Science Monitor. 1921. March 23.

29. Boston Daily Globe. 1921. May 23.

30. Washington Post. 1921. March 26.

31. New York Times. 1921. May 29.

32. New York Times. 1921. September 3.

33. Washington Post. 1921. September 4.

34. New York Times. 1921. October 6.

35. Atlanta Constitution. 1921. September 12.

36. Washington Post. 1921. September 13.

37. New York Times. 1922. April 22.

38. Grems-Doolittle Library. Charles Steinmetz Papers. Box 1. Folder 8.

39. New York Times. 1924. September 19.

40. Yorkshire Post and Leeds Intelligencer. 1924. September 10.

41. New York Times. 1925. July 16.

42. Washington Post. 1926. September 17.

43. Dorn H. Hugh Lincoln Cooper and the First Detente // Technology and Culture. 1979. № 2. P. 340-341.

44. New York Times. 1926. September 17.

45. Los Angeles Times. 1926. October 8.

46. Boston Daily Globe. 1926. October 7. 
47. Christian Science Monitor. 1926. October 28.

48. Hartford Courant. 1926. October 8.

49. The Scotsman. 1926. November 10.

50. Yorkshire Post and Leeds Intelligencer. 1926.

November 25.

51. Ball A. Imagining America: Influence and Imag-

es in Twentieth-Century Russia. New York, 2004.

52. Christian Science Monitor. 1926. December 7.

53. Los Angeles Times. 1927. May 24.

54. Boston Daily Globe. 1927. November 2.

55. Boston Daily Globe. 1928. August 1.

56. Aberdeen Press and Journal. 1928. July 10.
57. Chicago Daily Tribune. 1928. December 27.

58. Chicago Daily Tribune. 1929. April 14.

59. Rassweiler A. The Generation of Power: The History of Dneprostroi. Oxford, 1988.

60. Hughes T. American Genesis: A Century of Invention and Technological Enthusiasm, 1870-1970. Chicago, 2004.

61. Mumford L. Technics and Civilization. Chicago, 2010.

Исследование выполнено по заказу «Т Плюс Самара».

\section{RUSSIA ELECTRIFICATION PLAN IN THE USA AND UK PRESS ASSESSMENT OF THE 1920-1929} (C) 2018

Buranok Sergey Olegovich, doctor of historical sciences, professor of World History, Law and Methods of Teaching Department Samara State University of Social Sciences and Education (Samara, Russian Federation)

Abstract. The following paper deals with the research of the place and value of Russia electrification plan and its reflection in Great Britain and the USA public opinion. The study of information campaign around Russia electrification plan has its specifics and value: first, it gives a chance to establish new, unknown facts; secondly, to determine the level of knowledge of «Another» (in this case, American) society about the Soviet power; thirdly, to understand what place information about Russia electrification plan took in the USA and Great Britain in the system of the USSR image creation, the image of «the Soviet power revolution». This paper uses materials of the USA and Great Britain press about Russia electrification plan. Besides, the author analyzes the image of the Soviet power in the American and British society. The information campaign around Russia electrification plan could report to the world about the Soviet economy achievements as well as promote preparation (in the information plan) to the following large project - industrialization. Articles, reports, notes on Russia electrification plan helped to change the attitude towards Russia / the USSR in the USA and Great Britain and helped to correct the image of the USSR in the world.

Keywords: electrification; USSR economy; Russia electrification plan; periodicals of USA; power supply systems of USSR; Soviet heavy industry; periodicals of Great Britain; H. Wells; V.I. Lenin; public opinion; Dneproges; economic development of USSR; industrialization.

УДК 94

Статья поступила в редакцию 26.01.2017

\section{ОРГАНИЗАЦИОННАЯ СТРУКТУРА МИССИИ ШВЕДСКОГО КРАСНОГО КРЕСТА ПО ОКАЗАНИЮ ПОМОЩИ ГОЛОДАЮЩИМ САМАРСКОЙ ГУБЕРНИИ ВО ВРЕМЯ ГОЛОДА 1921-1923 ГОДОВ}

(C) 2018

Циденков Григорий Геннадиевич, кандидат социологических наук, доцент кафедры управления и сервиса Самарский государственный сочиально-педагогический университет (2. Самара, Российская Федераиия)

Аннотация. В период с декабря 1921 г. по август 1923 г. В Самарской губернии осуществляла гуманитарную деятельность экспедиция Шведского Красного Креста. В статье рассматриваются структура управления экспедицией, форма ее организации. Представлены кадровый состав и принципы, по которым строилось управление экспедиции. Участники экспедиции персонифицируются с указанием их должностей и круга обязанностей. Указываются причины нарастающего увеличения штата экспедиции. Основной массив данных, представленных в статье, получен в результате трехмесячной исследовательской работы в Национальном архиве Швеции (Riksarkivet) и впервые вводится в научный оборот. В статье приводится оценка, данная организации и эффективности работы Шведского Креста представителями советской власти в Самаре. Указаны все основные административные районы Самарской губернии, в которых осуществлялась непосредственная работа сотрудников Шведского Красного Креста. Представленные в статье материалы расширяют наше представление о деятельности иностранных гуманитарных миссий в Поволжье в 1921-1923 годах и могут использоваться для анализа эффективности деятельности экспедиции Шведского Красного Креста в Самарской губернии в указанный период.

Ключевые слова: голод 1921-1923 годов; иностранная помощь; Шведский Красный Крест; экспедиция Шведского Красного Креста; Международный комитет помощи России; Самарская губерния; управление; организационная структура; распределение продовольствия; производственная помощь.

Основным доступным источником информации, освещающей деятельность Шведского Красного Креста (далее - ШКК) в Поволжье во время голода 1921-1923 годов, в настоящее время является совместный сборник документов ГБУСО «Самарский областной государственный архив социально-политической истории» и ГБУСО «Центральный государственный архив Самарской области» «Голод в Средневолжском Крае в 20-30-е годы XX века. Том 1. Голод в Самарской губернии в 20-е годы XX века» [1]. 